\title{
PENGELOLAAN MANAJEMEN RESIKO GADAI NON-EMAS TIDAK TERTEBUS DI PEGADAIAN SYARIAH CABANG BLAURAN SURABAYA ${ }^{1}$
}

\author{
Dyah Palupi Dwi Cahyani \\ Departemen Ekonomi Syariah- Fakultas Ekonomi dan Bisnis-Universitas Airlangga \\ Email: dyahpalupidwicahya@gmail.com
}

Muhammad Nafik Hadi Ryandono

Departemen Ekonomi Syariah- Fakultas Ekonomi dan Bisnis-Universitas Airlangga

Email: muhammadnafik@feb.unair.ac.id

\begin{abstract}
:
This study aimed to know the mechanism of risk management of unredeemed nongold pawn in Blauran Sharia Pawnshop. Through the three phases of risk management, those are risk identification, risk ranking and risk control, Blauran Sharia Pawnshop was expected to minimize the risks, one of them is the unredeemed non-gold pawn. The research method used was qualitative. Research data is obtained by doing documentation and interviewing the informant that was the assistant deputy manager Pawnshop of Surabaya Regional Office, Head of Blauran Surabaya Sharia Pawnshop branch, and staff of Blauran Surabaya Sharia Pawnshop. The research showed that Blauran Sharia Pawnshop had implemented the risk management process in three phases, those are risk identification, risk ranking based on the most substantial and potential risk and lastly risk control by conducting an auction on non-gold pawning items that were not redeemed.
\end{abstract}

Keyword: Risk Management, sharia mortgage, sharia pawnshop,unreedemed non-gold pawn

\section{PENDAHULUAN}

Islam merupakan agama yang diciptakan Allah SWT paling sempurna diantara agama yang lain. Didalamnya terkandung seluruh aturan dan ajaran yang harus maupun tidak boleh dilakukan oleh umatnya. Mulai dari makanan yang halal maupun yang haram hingga pada bagaimana menyejahterakan umat Muslim itu sendiri. Hal sekecil apapun telah diatur dalam Islam, termasuk masalah ekonomi. Semuanya tidak luput dari pengawasan Allah SWT, sebab Allah SWT tidak ingin hamba-Nya menjadi penghuni neraka diakibatkan melanggar aturanNya.
Munculnya ekonomi Islam seakan membawa angin tersendiri pada masyarakat yang merasakan bahwa perekonomian saat ini sedang kurang menguntungkan bagi mereka yang berada di bawah garis perekonomian menengah kebawah.

Tujuan dari ekonomi Islam sendiri yakni mewujudkan tingkat pertumbuhan ekonomi jangka panjang serta memaksimalkan kesejahteraan manusia atau falah. Falah diartikan sebagai terpenuhinya kebutuhan individu masyarakat dengan tidak mengabaikan keseimbangan, kepentingan sosial, keseimbangan ekologi, dan tetap memperhatikan nilai-nilai keluarga serta

\footnotetext{
${ }^{1}$ Jurnal ini merupakan bagian dari skripsi Dyah Palupi Dwi Cahyani, NIM: 041114030 , yang diuji pada tanggal 18 Juli 2018.
} 
Cahyani, et al/Jurnal Ekonomi Syariah Teori dan Terapan Vol. 6 No. 3 Maret 2019: 446-460; PENGELOLAAN MANAJEMEN RESIKO GADAI NON-EMAS TIDAK TERTEBUS DI PEGADAIAN SYARIAH CABANG BLAURAN SURABAYA

norma-norma (Chapra, 2000). Disaat seperti sekarang dapat dilihat bahwa yang kaya semakin kaya dan yang miskin semakin miskin karena ketidakseimbangan tingkat kesejahteraan masyarakat.

Sifat ekonomi Islam yang universal tidak hanya ditujukan untuk umat Muslim saja namun juga seluruh umat manusia. Demi mewujudkan kemaslahatan ataupun kesejahteraan bagi rakyat, maka pemerintah Indonesia mendirikan lembaga keuangan, baik bank maupun non-bank. Pegadaian merupakan lembaga keuangan yang menyediakan fasilitas pinjaman dengan menggunakan jaminan tertentu, seperti emas atau barang-barang yang memiliki nilai jual. Jaminan dari nasabah tersebut digadaikan untuk kemudian ditaksir oleh Pegadaian.

Setelah dirasa Perum Pegadaian masih kurang cukup memenuhi kebutuhan masyarakat akan penyaluran dana, terutama untuk umat Muslim yang menginginkan bebas dari riba dan sesuai syariah, maka lahirlah Pegadaian Syariah. Pegadaian syariah merupakan pegadaian yang aktivitasnya meninggalkan hal-hal yang riba sebab diketahui bahwa dalam Islam riba merupakan hal yang diharamkan.

Hingga pada tahun 1990an terbit PP/10 yang menjadi tonggak awal berdirinya Pegadaian Syariah di Indonesia. Konsep operasional Pegadaian Syariah mengacu pada sistem administrasi modern yaitu azas rasionalitas, efisiensi, dan efektivitas yang diselaraskan dengan nilai-nilai Islam. Ketentuan-ketentuan dalam gadai syariah atau biasa disebut rahn sudah tercantum dalam FATWA DSN MUI No.9 Tahun 2000, sehingga nasabah (murtahin) tidak perlu ragu apabila menggadaikan barang (marhun) di pegadaian syariah.

Meski sudah sesuai syariah, namun pegadaian syariah juga memiliki resiko yang hampir sama dengan lembaga keuangan lain. Sebelum hal ini benarbenar terjadi maka pegadaian syariah menerapkan manajemen resikonya disini. Manajemen resiko bertujuan memberikan perlindungan kepada setiap pejabat yang memiliki wewenang pada pegadaian syariah terhadap akibat buruk yang mungkin saja terjadi disebabkan adanya resiko. Di Surabaya, khususnya di Pegadaian Syariah Blauran, salah satu risiko yang dapat dialami adalah risiko yang disebabkan oleh ketidakmampuan nasabah dalam melakukan penebusan barang jaminannya. Melalui penerapan manajemen risiko yang tepat diharapkan risiko-risiko semacam ini dapat diminimalisir agar tidak menimbulkan kerugian atau penyimpangan dari tujuan awal penyaluran dana oleh Pegadaian Syariah Blauran.

\section{LANDASAN PUSTAKA}

Manajemen resiko adalah suatu proses identifikasi, pengukuran, dan kontrol dari suatu resiko yang mengancam dan menyebabkan kegagalan dimana kerugian tersebut dapat dikurangi sehingga kerugian hanya 
Cahyani, et al/Jurnal Ekonomi Syariah Teori dan Terapan Vol. 6 No. 3 Maret 2019: 446-460; PENGELOLAAN MANAJEMEN RESIKO GADAI NON-EMAS TIDAK TERTEBUS DI PEGADAIAN SYARIAH CABANG BLAURAN SURABAYA

terjadi sebagian saja dan tidak sampai keseluruhan. Dapat dikatakan pula manajemen resiko merupakan salah satu sistem pengaman dalam perusahaan dalam mengatasi suatu resiko sebelum resiko tersebut terjadi. Fungsi-fungsi pokok dari diterapkannya manajemen resiko antara lain:

1) Menemukan kerugian potensial

Upaya yang dilakukan untuk menemukan atau mengidentifikasi seluruh resiko murni yang dihadapi perusahaan

2) Mengevaluasi kerugian potensial

Upaya yang dilakukan untuk menilai semua kerugian potensial yang dihadapi perusahaan

3) Menentukan cara penanggulangan resiko

Upaya yang dilakukan perusahaan untuk menentukan langkah-langkah tepat apa yang dapat dilakukan untuk menangani suatu resiko.

Sebelum mengambil keputusan, suatu perusahaan harusalah memahami terlebih dahulu tentang resiko. Tujuan dari memahami resiko adalah untuk mengelola resiko itu sendiri.Pada semua perusahaan ataupun lembaga keuangan, baik lembaga keuangan bank maupun lembaga keuangan non-bank, resiko yang dihadapi hampir sama. Sesuai surat edaran dari Bank Indonesia tentang penerapan manajemen resiko bagi bank umum hanya menyantumkan delapan jenis resiko yakni resiko kredit, resiko pasar, resiko likuiditas, resiko operasional, resiko hukum, resiko reputasi, resiko strategik, dan resiko kepatuhan.

Umumnya, manajemen resiko dilakukan melalui beberapa tahap. Menurut Hopkin dalam labal (2006:20) berikut merupakan disiplin manajemen resiko yang sudah sesuai dengan ajaran Islam:

1. Identifikasi resiko

Kegiatan identifikasi resiko sangat penting, pada tahap awal, pihak manajemen perusahaan melakukan tindakan berupa identifikasi atau pengenalan setiap bentuk resiko yang dialami perusahaan.

2. Rangking Resiko

Rangking atau evaluasi resiko yang telah diidentifikasi perlu dilakukan karan dengan cara tersebut, perusahaan dapat mengetahui resiko yang dominan atau yang paling tinggi dan mana resiko yang paling rendah.

\section{Pengendalian Resiko}

Langkah selanjutnya dan yang terakhir setelah melalui proses rangking resiko yaitu pengendalian resiko. pengendalian resiko dilakukan untuk mengetahui apakah tiaptiap resiko yang telah diidentifikasi tersebut berada dalam kendali.

$$
\text { Menurut Hanafi (2012:245), ada }
$$
beberapa model pengelolaan resiko yakni:

1. Penghindaran

2. Ditahan (retention

3. Diversivikasi

4. Transfer resiko

5. Pengendalian resiko

6. Pendanaan resiko 
Cahyani, et al/Jurnal Ekonomi Syariah Teori dan Terapan Vol. 6 No. 3 Maret 2019: 446-460; PENGELOLAAN MANAJEMEN RESIKO GADAI NON-EMAS TIDAK TERTEBUS DI PEGADAIAN SYARIAH CABANG BLAURAN SURABAYA

Menurut lqbal (2005, 21-23), respon atau cara mengelola resiko tersebut bisa dijelaskan melalui beberapa hal sebagai berikut:

a. Menerima atau menahan resiko

b. Menghindari atau mengeliminir resiko

C. Menetralisir atau mengimbangi resiko

d. Mengendalikan atau mengurangi resiko

e. Membagi resiko dengan pihak yang lain

Kebutuhan hidup yang terus meningkat, disebabkan faktor konsumerisme yang tinggi, membuat seseorang terus berusaha untuk memenuhii kebutuhannya. Selain faktor konsumerisme, kebutuhan modal dalam membuka atau mengembangkan usaha juga membutuhkan lembaga-lembaga keuangan sebagai alternatif bantuan. Selain sudah banyak diketahui bahwa perbankan mampu memberikan kredit sesuai dengan yang masyarakat ajukan dan dengan syarat-syarat yang disetujui, ada pula yang memilih untuk menjaminkan hartanya pada lembaga keuangan seperti pegadaian. Saat ini sudah ada sekitar 4411 outlet pegadaian milik pemerintah yang tersebar dan legal diseluruh Indonesia.

Gadai merupakan penyerahan suatu barang bergerak yang digunakan sebagai jaminan untuk mendapatkan pendanaan dan barang yang dijadikan jaminan tersebut dapat ditebus kembali sesuai perjanjian antara nasabah dengan lembaga gadai. Sedangkan lembaga yang melakukan gadai disebut
Pegadaian. Di Indonesia, Perum pegadaian merupakan satu-satunya badan usaha yang resmi dan memiliki ijin untuk melakukan kegiatannya sebagai lembaga keuangan dibidang pembiayaan dalam wujud penyaluran dana ke masyarakat.

Ada dua jenis pegadaian yang saat ini berkembang dimasyarakat yakni pegadaian konvensional dan pegadaian syariah.

Berdasarkan hukum gadainya yang memang berbeda, yakni pegadaian konvensional menggunakan dasar hukum gadai Undang Undang buatan pemerintah sedangkan pegadaian syariah menggunakan landasan Al Quran yang murni dari Allah, maka terdapat banyak sekali perbedaan antara keduanya. Perbedaan antara pegadaian konvensional dan syariah, antara lain:

1) Pegadaian konvensional

a. Gadai berdasarkan hukum perdata tidak hanya berprinsip tolong menolong tetapi juga untuk mendapatkan keuntungan

b. Pada hukum perdata hak gadai hanya berlaku pada benda bergerak

c. Adanya tingkat bunga dimana sifatnya akumulatif dan berlipat ganda

d. Tingkat bunga 10\%-14\% untuk jangka waktu 4 bulan

e. Menurut hukum perdata, harus melalui satu lembaga yaitu PT.Pegadaian 
Cahyani, et al/Jurnal Ekonomi Syariah Teori dan Terapan Vol. 6 No. 3 Maret 2019: 446-460; PENGELOLAAN MANAJEMEN RESIKO GADAI NON-EMAS TIDAK TERTEBUS DI PEGADAIAN SYARIAH CABANG BLAURAN SURABAYA

2) Pegadaian syariah (Rahn)

a. Rahn dalam hukum Islam dilakukan berdasarkan sukarela atas dasar tolong menolong tanpa mencari keuntungan atau dengan mencari untung yang wajar

b. Rahn berlaku pada seluruh benda, baik yang bergerak maupun yang tidak bergerak

c. Tidak ada istilah bunga atau riba, biaya penitipan, pemeliharaan, penjagaan, dan penaksiran

d. Rahn berdasarkan hukum Islam bisa dilakukan tanpa melalui suatu lembaga seperti pegadaian

e. Hanya memungut biaya, termasuk asuransi, sebesar $4 \%$ selama 2 bulan.

Sejarah awal pendirian Pegadaian dimulai ketika Indoneisa masih dijajah oleh Belanda (VOC) mendirikan Ban Van Leening didirikan pada 20 Agustus 1746 di Batavia (Jakarta). Pada tahun 1811-1816, Inggris mengambil alih kekuasaan dan membubarkan Ban Van Leening kemudian memberi kekuasaan kepada masyarakat untuk mendirikan pegadaian dibawah lisensi pemerintah daerah atau liecentie stelsel. Liecentie stelsel lalu diubah menjadi patch stelsel. Pada masa Jepang, pegadaian disebut sitji eigeikyuku. Pasca dikelola Pemerintah Republik Indonesia, Pegadaian telah beberapa kali berganti status yaitu sebagai:

1) Perusahaan Negara (PN) pada 1 Januari 1961
2) Perusahaan Jawatan (Perjan) berdasarkan Peraturan Pemerintah No.7/1969

3) Perusahaan Umum (Perum) berdasarkan Peraturan Pemerintah No.10/1990 yang diperbaharui dengan Peraturan Pemerintah No.103/2000

4) Perseroan pada tahun 2011 berdasarkan Peraturan Pemerintah No.51/2011.

Peraturan Pemerintah No.10 tanggal 1 April 1990 merupakan tonggak awal bangkitnya pegadaian. Kemudian muncul PP No.103/200 yang merupakan landasan Perum. Melalui kajian yang sangat panjang, berhasil disusun konsep pendirian Unit Layanan Gadai Syariah yang merupakan awal dibentuknya divisi khusus untuk menangani kegiatan usaha syariah melalui bantuan Bank Muamalat Indonesia.

Secara etimologi, rahn diartikan sebagai al-tsubut wa al-dawam yang berarti tetap dan lama dan diartikan pula sebagai al-habsu walluzum yang berati pengekangan dan keharusan (tertahan). Menurut terminologi syara', rahn berarti penahanan terhadap suatu barang dengan hak sehingga dapat dijadikan sebagai pembayaran dari barang tersebut dan dapat diambil sebagian manfaat dari barang itu.

Secara umum, hukum rahn terbagi menjadi dua yakni sahih dan ghair sahih (fasid). Rahn sahih yaitu rahn yang mengandung unsur-unsur kemaslahatan atau bermanfaat dan sesuai dengan kebutuhan. Sedangkan rahn fasid yaitu 
Cahyani, et al/Jurnal Ekonomi Syariah Teori dan Terapan Vol. 6 No. 3 Maret 2019: 446-460; PENGELOLAAN MANAJEMEN RESIKO GADAI NON-EMAS TIDAK TERTEBUS DI PEGADAIAN SYARIAH CABANG BLAURAN SURABAYA

rahn yang didalamnya mengandung syarat-syarat yang tidak sesuai kebutuhan atau lebih mengarah pada sesuatu yang haram, seperti contohnya mensyaratkan bahwa barang harus berada di bawah tanggung jawab rahin.

Dalam mengerjakan suatu pekerjaan atau ibadah yang baik dan benar tentu dibutuhkan aturan-aturan yang berguna untuk mengatur amalan tersebut, seperti adanya syarat dan rukun. Menurut jumhur ulama rukun rahn ada empat, yaitu:

1) Shigat (lafal ijab dan qabul)

2) Rahin (orang yang berhutang) dan Murtahin (pemberi hutang)

3) Marhun (harta yang dijadikan jaminan)

4) Marhun bih (hutang)

Tidak semua nasabah memiliki riwayat gadai yang baik. Tidak jarang nasabah melakukan pelanggaran kesepakatan dengan Pegadaian, sebagai contohnya adalah tidak melakukan penebusan barang yang digunakan sebagai jaminan. Akibat masalah barang pinjaman yang tidak tertebus ini, maka pihak Pegadaian membuat aturan yang mengharuskan nasabah untuk melakukan penebusan barang jaminan maksimal 14 hari atau dua minggu setelah tanggal jatuh tempo. Apabila dalam tempo waktu yang sudah disepakati tersebut tidak dilakukan penebusan, maka Pegadaian berhak untuk menjual barang jaminan tersebut kepada umum melalui lelang.

Lelang adalah penjualan barang dimuka umum yang dipimpin oleh Pejabat
Lelang dengan cara penawaran harga secara terbuka atau lisan dan atau tertutup atau tertulis yang didahului dengan pengumuman lelang. Karena itu rencana lelang pada prisipnya harus lebih dahulu diumumkan kepada masyarakat. Di Indonesia sendiri terdapat dua jenis lelang yang sering dilakukan, yakni:

a. Lelang eksekusi

Lelang eksekusi merupakan lelang berdasarkan keputusan pengadilan atau dokumen-dokumen yang setara. Hal ini terjadi akibat dari pelanggaran perjanjian yang sudah disepakati sebelumnya. Barang yang dilelang dapat berupa harta yang bergerak maupun harta yang tidak bergerak.

b. Lelang non-eksekusi

Lelang non-eksekusi adalah lelang barang milik perorangan atau badan usaha, swasta, atau badan hukum yang hakikatnya dilakukan dengan sukarela.

Syarat-syarat dilakukannya lelang, antara lain:

1. Harus benar-benar ada orang yang dihimpun atau dikumpulkan dan ada barang yang dijual

2. Orang-orang yang dihimpun atau dikumpulkan benar-benar ada kemauan untuk mengikatkan diri dalam jual beli tersebut

3. Peminat tidak dapat diketahui dan tidak dapat ditunjuk sebelumnya. Peminat baru diketahui setelah lelang selesai dan berhasil dilakukan.

Dalam hal lelang, digunakan asasasas yang mendasari dilakukannya suatu 
Cahyani, et al/Jurnal Ekonomi Syariah Teori dan Terapan Vol. 6 No. 3 Maret 2019: 446-460; PENGELOLAAN MANAJEMEN RESIKO GADAI NON-EMAS TIDAK TERTEBUS DI PEGADAIAN SYARIAH CABANG BLAURAN SURABAYA

lelang. Asas-asas yang harus diterapkan lelang, antara lain:

a. Asas Keterbukaan (Transparency)

b. Asas Efisiensi (Efficiency)

c. Asas Persaingan (Competition)

d. Mampu dipertanggung jawabkan (Accountability)

Penjualan secara lelang dapat dipertanggung jawabkan kepastian hukumnya sebab dilakukan dihadapan Pejabat Lelang selaku pejabat umum yang ditunjuk undang-undang untuk memimpin lelang dan membuat Risalah Lelang sebagai kata yang otentik.

Selain memiliki syarat-syarat dan asas-asas yang harus diterapkan, lelang juga memiliki peraturan yang juga harus ditaati. Aturan-aturan tersebut diatur dalam perundangan-undangan yang berlaku di negara Indonesia. Dasar hukum lelang di Indonesia dipisahkan menjadi ketentuan khusus dan ketentuan umum. Termasuk didalam ketentuan khusus yaitu:

1. Peraturan lelang atau Vendu Reglement (Stbl.1908 No.189)

2. Instruksi lelang atau Vendu Instructie (Stbl.1908 No.190)

3. Peraturan Pemungutan Bea Lelang untuk pelelangan dan penjualan umum (Stbl.1949 No.390)

Sedangkan ketentuan khusus
diatur dalam keputusan Menteri Keuangan, yaitu:

1. Peraturan Menteri Keuangan Nomor: 40/PMK.07/2006 Tentang Petunjuk Pelaksanaan Lelang
2. Peraturan Menteri Keuangan Nomor: 41/PMK.07/2006 Tentang Pejabat
Lelang Kelas I

3. Peraturan Menteri Keuangan Nomor: 1 18/PMK.07/2005 Tentang Balai Lelang

4. Peraturan Menteri Keuangan Nomor: 119/PMK.07/2005 Tentang Pejabat Lelang Kelas II

5. Keputusan Dirjen Piutang dan Lelang Negara Nomor: KEP-02/PL/2006 Tentang Petunjuk Teknis Pelaksanaan Lelang

6. Keputusan Dirjen Piutang dan Lelang Negara Nomor: KEP-01/PL/2006 Tentang Pedoman Administrasi Perkantoran dan Pelaporan Kantor Pejabat Lelang Kelas II

Undang-undang lainnya: UU Hukum Pidana, Perdata, Kepabeanan, Pajak, UU Keuangan Negara, UU Perbendaharaan, UU Hak Tanggungan, UU Jaminan Fidusia, UU Perbankan, dan sebagainya.

Sebelum lelang dilaksanakan ada beberapa prosedur yang harus dilakukan, yaitu:

a. Pemberitahuan Lelang

b. Persiapan Lelang

c. Pelaksanaan Lelang

Dalam Islam, lelang diistilahkan sebagai jual beli muzayadah, yang artinya saling menambah. Lelang diqiyaskan atau disamakan dengan jual beli, sebab ada pihak penjual dan pihak pembeli. Selain itu, berdasarkan Fatwa DSN MUI No.25 tentang rahn maka penjualan marhun atau lelang diperbolehkan apabila rahin tidak dapat melunasi hutangnya hingga waktu jatuh tempo yang telah disepakati. 
Cahyani, et al/Jurnal Ekonomi Syariah Teori dan Terapan Vol. 6 No. 3 Maret 2019: 446-460; PENGELOLAAN MANAJEMEN RESIKO GADAI NON-EMAS TIDAK TERTEBUS DI PEGADAIAN SYARIAH CABANG BLAURAN SURABAYA

Islam melarang menawar barang yang sudah ditawar oleh orang lain. Larangan menawar barang dalam lelang ini berlaku apabila lelang sudah ditutup dan barang sudah dibawa oleh pemenang lelang, karena sudah terjadi kesepakatan antara penjual dan pembeli dalam lelang tersebut. Tetapi, apabila lelang tersebut belum ditutup, maka tidak ada larangan bagi peserta lelang atau pembeli untuk menawar.

\section{METODE PENELITIAN}

Data yang terkumpul akan dilakukan pengujian secara kualitatif yaitu metode penelitian yang digunakan untuk meneliti, dimana peneliti merupakan instrumen kunci, teknik pengumpulan data dilakukan secara triangulasi (gabungan), analisis data, dan hasil penelitian kualitatif.

Penelitian ini digunakan untuk menjawab rumusan masalah penelitian tentangmekanisme manajemen resiko gadai non-emas tidak tertebus di Pegadaian Syariah Blauran Surabaya.

\section{Identifikasi Variabel}

Identifikasi variabel dalam rumusan masalah tersebut menjadi acuan peneliti dalam menentukan ruang lingkup penelitian. Ruang lingkup penelitian terbatas padajenis-jenis resiko yang dihadapi oleh Pegadaian Syariah Blauran dan mekanisme yang dilakukan untuk meminimalisir resiko yang mungkin terjadi khususnya gadai non-emas yang tidak tertebus.

$$
\text { Pengelolaan resiko di Pegadaian }
$$

Syariah Blauran Surabaya dari sudut pandang perusahaan sebab perusahaan yang melakukan aktivitas ekonomi.

\section{Ruang Lingkup Penelitian}

Penelitian yang dimaksud adalah penelitian yang dilakukan dalam rangka menjawab rumusan masalah penelitian yaitu bagaimana pengaplikasian manajemen risiko dalam pengelolaan gadai non-emas tidak tertebus. Melihat rumusan masalah tersebut maka peneliti menentukan ruang lingkup dalam peneltian ini yaitu terbatas pada:

1. Penelitian ini difokuskan pada aktifitas manajemen resiko gadai non-emas tidak tertebus. Hal ini karena yang diteliti adalah upaya Pegadaian Syariah dalam mengelola resiko gadai non-emas tidak tertebus.

2. Membatasi penelitian ini hanya pada karyawan Pegadaian yang bertugas sebagai pihak pengelola resiko gadai non-emas tidak tertebus.

\section{Teknik pengumpulan data}

Teknik pengumpulan data yang dipakai dalam penelitian ini menggunakan cara sebagai berikut:

1. Menggunakan multisumber bukti

2. Mengumpulkan database

3. Menjaga keberadaan rantai bukti

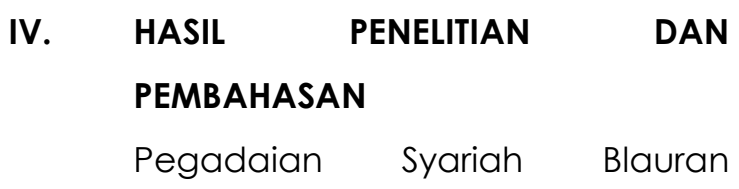

Surabaya terletak ditempat yang cukup strategis, dimana outletnya terletak ditempat-tempat yang ramai dikunjungi masyarakat seperti pasar dan mall dan berada tepat dipinggir jalan raya. Pegadaian Syariah Blauran saat ini telah 
Cahyani, et al/Jurnal Ekonomi Syariah Teori dan Terapan Vol. 6 No. 3 Maret 2019: 446-460; PENGELOLAAN MANAJEMEN RESIKO GADAI NON-EMAS TIDAK TERTEBUS DI PEGADAIAN SYARIAH CABANG BLAURAN SURABAYA

berusia 11 tahun dan diresmikan pada tanggal 1 April 2006 oleh Direktur Utama Kantor Wilayah Perum Pegadaian Syariah Surabaya pada masa itu. Konsep operasi Pegadaian Syariah sendiri berlandaskan pada sistem administrasi modern yakni azas rasionalitas, efisiensi, dan efektivitas yang diselaraskan dengan nilai-nilai Islam. Selain itu Pegadaian Syariah juga berpedoman pada Al Quran dan Al Hadits dalam menjalankan kegiatan operasionalnya. Prinsip inilah yang membuat Pegadaian Syariah memiliki karakteristik tidak adanya pengambilan riba dalam berbagai bentuk transaksi dan produknya, menjadikan uang sebagai alat tukar bukan sebagai alat komoditas yang dijual, dan melakukan bisnis untuk mendapatkan imbalan atas jasa atau bagi hasil.

\section{Produk-Produk Pegadaian Syariah}

1. Rahn (gadai syariah) merupakan skim pinjaman yang menggunakan sistem gadai sesuai syariah dengan menggunakan barang jaminan berupa emas dan benda bergerak.Jika seorang nasabah menggadaikan barangnya maka untuk menghitung nilai taksiran digunakan rumus sebagai berikut:

Nilai Taksiran $=$ Prosentase nilai jenis

barang $x$ HPS yang berlaku

Dari hasil nilai taksiran tersebut maka akan dapat digunakan untuk menentukan besar pinjaman yang dapat diberikan kepada nasabah melalui rumus sebagai berikut:
Nilai Pinjaman $=$ Nilai Taksiran $\times$ Prosentase Nilai Taksiran

Sebagai contoh yakni dengan menggunakan hp atau laptop sebagai barang jaminan, dimana hp dan laptop memiliki prosentase nilai

2. Arrum merupakan produk pembiayaan yang diciptakan untuk memudahkan pengusaha-pengusaha kecil mendapatkan modal usaha dengan menggunakan jaminan BPKB kendaraan ataupun emas

3. Amanah yakni produk pembiayaan Pegadaian Syariah yang berprinsip syariah kepada pegawai negeri sipil dan karyawan swasta untuk memiliki kendaraan bermotor dengan cara mengangsur

4. Tabungan emas merupakan produk Pegadaian yang memberikan layanan pembelian dan penjualan emas dengan fasilitas titipan

5. Mulia merupakan layanan pembiayaan emas batangan baik secara tunai maupun angsuran dengan prinsip syariah

6. MPO (Multi Payment Online)

Pada tahun 2017, PT.Pegadaian (Persero) membukukan laba bersih sebesar Rp.2,5 Triliun. Laba bersih tersebut tumbuh $13,72 \%$ dibanding tahun 2016 yang mencapai Rp.2,2 Triliun.

\section{Manajemen Resiko Gadai}

Dalam menjalankan kegiatan operasionalnya dibidang gadai dan pembiayaan, Pegadaian Syariah Blauran tidak menampik jika ada resiko-resiko 
Cahyani, et al/Jurnal Ekonomi Syariah Teori dan Terapan Vol. 6 No. 3 Maret 2019: 446-460; PENGELOLAAN MANAJEMEN RESIKO GADAI NON-EMAS TIDAK TERTEBUS DI PEGADAIAN SYARIAH CABANG BLAURAN SURABAYA

yang dihadapi setiap harinya. Seringnya resiko yang dihadapi merupakan human error dari karyawan Pegadaian Syariah Blauran itu sendiri. Tidak jarang beberapa kali karyawan harus mengganti dengan vang pribadi akibat resiko tersebut. Salah satu yang dilakukan oleh PT. Pegadaian atau mungkin juga dilakukan oleh perusahaan-perusahaan yang bergerak dibidang keuangan maupun nonkeuangan yakni dibentuknya manajemen resiko. Menurut Djohanputro (2008) bahwa manajemen resiko merupakan proses terstruktur dan sistematis dalam mengidentifikasi, mengukur, memetakan, mengembangkan, alternatif penanganan resiko, memonitor, dan mengendalikan penanganan resiko.

\section{Manajemen Resiko Gadai Non-Emas}

Seperti yang sudah banyak diketahui bahwa dalam menjalankan usaha apapun pasti akan ditemui resikoresiko, baik itu resiko yang terduga maupun yang tidak terduga.. Tidak terkecuali pada PT. Pegadaian, baik pegadaian konvensional maupun syariah, dua-duanya tentu memiliki resiko-resiko yang setiap hari dihadapi. Dengan adanya resiko-resiko yang muncul, baik secara terduga maupun tidak terduga tersebut, maka PT. Pegadaian sebagai induk dari Pegadaian Syariah membentuk manajemen resiko untuk mengantisipasi resiko-resiko yang muncul tersebut.Manajemen resiko gadai nonemas didefinisikan sebagai stepby step yang dilakukan oleh pegadaian dalam mengidentifikasi, mengukur, memantau, serta mengendalikan resiko yang muncul dari barang-barang jaminan non-emas.

\section{Mekanisme Manajemen Resiko Gadai Non-Emas}

Sebagai induk dari pegadaian syariah, PT. Pegadaian sejatinya sudah memberikan benteng atau perlindungan terhadap seluruh pemangku jabatan, terutama yang ada di lapangan seperti di outlet-outlet pegadaian, baik konvensional maupun syariah, yang tersebar diseluruh Indonesia. Perlindungan tersebut berupa manajemen resiko yang wajib diterapkan di seluruh tubuh dari PT. Pegadaian termasuk anak perusahaannya.Dengan adanya manajemen resiko, diharapkan dapat memberikan hal positif bagi perusahaan, yakni apabila terjadi dampak negatif tidak akan seburuk sebelumnya sebab sudah dilakukan antisipasi terlebih dahulu dan para pemangku jabatan bisa mengambil keputusan lebih baik lagi dari sebelumnya.

Mekanisme yang dilakukan oleh manajemen resiko terutama untuk barang gadai non-emas sebenarnya hampir sama dengan barang gadai yang lain seperti emas, hanya berbeda bentuk barangnya saja, meliputi:

1. Identifikasi

Berdasarkan hasil wawancara proses ini perlu dibuat terlebih dahulu daftar pertanyaan-pertanyaan yang berhubungan dengan harta yang dimiliki oleh perusahaan serta operasional yang dijalankan oleh perusahaan. Kedua, perusahaan akan 
Cahyani, et al/Jurnal Ekonomi Syariah Teori dan Terapan Vol. 6 No. 3 Maret 2019: 446-460; PENGELOLAAN MANAJEMEN RESIKO GADAI NON-EMAS TIDAK TERTEBUS DI PEGADAIAN SYARIAH CABANG BLAURAN SURABAYA

menyusun laporan keuangan seperti neraca dengan tujuan agar resiko dapat dianalisa melalui laporan keuangan perusahaan. Kemudian yang ketiga adalah inspeksi langsung ke lapangan dengan tujuan agar dapat mengetahui peran tiap-tiap karyawan yang ada pada perusahaan dan sebagai sarana bertukar pikiran untuk dapat menanggulangi resiko apabila resiko terjadi.

2. Pengukuran

Berdasarkan hasil wawancara maka ditarik kesimpulan bahwa resiko perlu diukur untuk dapat diketahui seberapa penting resiko tersebut. Pengukuran tersebut akan membuat perusahaan menjadi lebih sadar dan waspada terhadap dampak yang dapat ditimbulkan oleh suatu resiko.

3. Pemantauan

Berdasarkan hasil wawancara diketahui bahwa semua yang berhubungan dengan operasional perusahaan, baik cabang maupun pusat, harus dilakukan sesuai dengan Standar Operasional Perusahaan atau SOP. Hal ini memiliki manfaat untuk perusahaan dimana dalam SOP ini tentu sudah diberikan step-step atau cara-cara ketika akan menghadapi resiko, ketika sedang menghadapi resiko, hingga pada ketika resiko telah terjadi.

4. Pengendalian

Pada proses ini, hal-hal yang dilakukan yakni memilah pilihan-pilihan mana yang bisa mengurangi dampak dari terjadinya resiko, lalu menentukan prosedur atau kebijakan apa yang perlu diambil. Cara yang dilakukan oleh perusahaan dalam menghadapi gadai non-emas tidak tertebus adalah melalui lelang, sehingga PT.Pegadaian tidak menanggung kerugian yang cukup besar.

$$
\text { Pada prakteknya dilapangan, }
$$
seperti yang dilakukan pula oleh Pegadaian Syariah Blauran, ada beberapa tahap yang dilakukan sebagai bagian dari manajemen resikonya, yaitu:

a. Tahap mengetahui profil atau karakteristik nasabah yang mengajukan pembiayaan. Dari diketahuinya karakteristik nasabah tersebut, maka pegadaian syariah bisa tahu di level mana resiko atas nasabah tersebut, apakah nasabah tersebut merupakan orang yang jujur, baik, serta bertanggung jawab.

b. Tahap mengamati usaha yang dijalankan nasabah. Pegadaian syariah mengidentifikasi apakah nasabah tersebut merupakan orang yang memiliki keahlian dalam mengelola usahanya tersebut sebab karakter yang baik belum tentu menentukan apakah nasabah tersebut mampu mengelola usahanya dengan baik.

C. Tahap jaminan yaitu pada tahap ini pegadaian syariah mengidentifikasi nilai jual dari barang jaminan dan ada tidaknya masalah hukum pada barang jaminan tersebut.

\section{Resiko Gadai Non-Emas Tidak Tertebus}

Pada lembaga keuangan, baik perbankan maupun non-perbankan, 
Cahyani, et al/Jurnal Ekonomi Syariah Teori dan Terapan Vol. 6 No. 3 Maret 2019: 446-460; PENGELOLAAN MANAJEMEN RESIKO GADAI NON-EMAS TIDAK TERTEBUS DI PEGADAIAN SYARIAH CABANG BLAURAN SURABAYA

tentu tidak terlepas dari resiko-resiko yang dihadapi. Resiko-resiko tersebut diantaranya yaitu resiko kredit, resiko pasar, resiko operasional, resiko likuiditas, resiko hukum, resiko stratejik, resiko kepatuhan, dan resiko reputasi. Pada Pegadaian Syariah Blauran ada beberapa resiko yang biasanya dapat dilakukan oleh karyawan dan stafnya atau human error. Selain itu ada pula resiko yang dialami oleh Pegadaian jika barang gadai non-emas tidak tertebus, yaitu:

1. Nilai dari barang tersebut akan semakin turun seiring berjalannya waktu disebabkan oleh faktor usia barang dan juga faktor teknologi.

2. Barang yang disimpan terlalu lama bisa saja mengalami kerusakan jika kurang terawat atau terlalu lama berada di gudang penyimpanan.

\section{Mekanisme Manajemen Resiko Gadai Non-Emas Tidak Tertebus}

Manajemen resiko dibentuk oleh Pegadaian Syariah dengan tujuan untuk mengantisipasi resiko-resiko yang bisa saja terjadi atau jika resiko sudah terjadi maka dampaknya bisa dikurangi agar tidak menyebabkan kerugian terlalu besar untuk perusahaan. Adapun cara-cara atau mekanisme yang dilakukan oleh manajemen resiko Pegadaian Syariah apabila terjadi gadai non-emas yang tidak tertebus sesuai dengan tahap-tahap yang dikemukakan oleh Hopkin dalam lqbal (2006:20):

1. Identifikasi resiko
Berdasarkan hasil wawancara, maka hal yang pertama dilakukan oleh Pegadaian Syariah Blauran dalam menjalankan manajemen resikonya yakni dengan meminta identitas resmi nasabah. Selain itu harus ada pula barang yang dijadikan untuk diserahkan kepada Pegadaian Syariah beserta surat-suratnya sebagai bukti legalitas barang tersebut. Setelah dilakukan pengecekan identitas dan barang jaminan baru dilakukan penaksiran nilai dari barang jaminan.

2. Rangking Resiko Menurut labal (2005:20), rangking atau evaluasi resiko yang sudah diidentifikasi perlu dilakukan karena melalui cara ini perusahaan dapat mengetahui resiko yang dominan atau yang paling tinggi serta resiko mana yang paling rendah. Berdasarkan hasil wawancara, disimpulkan bahwa gadai tidak tertebus merupakan resiko yang paling berpengaruh dalam proses gadai syariah di Pegadaian Syariah Blauran.

3. Pengendalian Resiko

Dari empat cara dalam mengendalikan resiko, Pegadaian Syariah menerapkan tiga cara yaitu:

a. Cara mengendalikan atau mengurangi resiko dengan cara meminta identitas resmi nasabah beserta barang jaminannya

b. Cara menerima atau menahan resiko sebab barang yang tidak tertebus masih dapat dijual atau dilelang untuk mengurangi kerugian 
Cahyani, et al/Jurnal Ekonomi Syariah Teori dan Terapan Vol. 6 No. 3 Maret 2019: 446-460; PENGELOLAAN MANAJEMEN RESIKO GADAI NON-EMAS TIDAK TERTEBUS DI PEGADAIAN SYARIAH CABANG BLAURAN SURABAYA

c. Cara menetralisasi atau mengimbangi resiko yaitu dengan cara menjual secara umum melalui lelang barang jaminan yang tidak tertebus tersebut.

\section{Lelang di Pegadaian Syariah}

Menurut Keputusan Menteri Keuangan Nomor 3014/KMK.1/2002 dalam pasal 1, lelang adalah penjualan barang yang terbuka untuk umum, baik secara langsung maupun melalui media elektronik, dengan cara penawaran harga secara lisan dan atau tertulis yang didahului dengan usaha mengumpulkan peminat. Ada dua jenis lelang yang dikenal di Indonesia secara umum, yaitu:

1. Lelang eksekusi

Lelang eksekusi merupakan lelang berdasarkan keputusan pengadilan atau dokumen-dokumen yang setara.

2. Lelang non-eksekusi

Lelang non-eksekusi adalah lelang barang milik perorangan atau badan usaha, swasta, atau badan hukum yang hakikatnya dilakukan dengan sukarela.

Pada Pegadaian, lelang yang dilakukan yakni lelang eksekusi tetapi yang dapat dilelang hanya harta bergerak saja, seperti kendaraan, mesinmesin, elektronik. Pegadaian tidak dapat melelang harta tidak bergerak sebab yang demikian hanya dapat dilakukan oleh balai lelang.

Sesuai prinsipnya yang syariah, maka Pegadaian Syariah dalam melakukan eksekusi atau lelang akan lebih pro kepada nasabah. Hal ini dikarenakan tujuan dari Pegadaian Syariah adalah untuk mensejahterkan masyarakat dan membantu masyarakat yang membutuhkan dana agar tidak terjerat riba. Tujuan lelang tersebut yakni untuk mengambil pokok pinjaman, biaya ijarah, dan biaya lelangnya saja. Jika setelah lelang didapati ada kelebihan dana, maka nasabah berhak untuk mengambil kelebihan dana tersebut dengan jangka waktu yang diberikan oleh Pegadaian Syariah selama satu tahun. Apabila lewat dari jangka waktu satu tahun tersebut dana tidak juga diambil maka Pegadaian Syariah akan menyalurkannya kepada baitul maal sebagai dana kebajikan umat. Namun apabila masih terdapat kekurangan setelah proses lelang selesai, maka nasabah juga wajib untuk melunasi kekurangan dari hasil penjualan atau lelang barang jaminannya tersebut dimana Pegadaian Syariah juga sudah turut serta membantu nasabah dalam melakukan penebusan barang melalui lelang.

\section{SIMPULAN}

Berdasarkan hasil penelitian, didapatkan tahapan atau mekanisme yang digunakan oleh manajemen resiko dalam mengelola gadai non-emas tidak tertebus di Pegadaian Syariah Cabang Blauran Surabaya:

a. Meninjau dari identifikasi resiko yang dilakukan oleh Pegadaian Syariah Blauran dilakukan pengecekan kelengkapan dokumen nasabah maupun barang dan menaksir harga 
Cahyani, et al/Jurnal Ekonomi Syariah Teori dan Terapan Vol. 6 No. 3 Maret 2019: 446-460; PENGELOLAAN MANAJEMEN RESIKO GADAI NON-EMAS TIDAK TERTEBUS DI PEGADAIAN SYARIAH CABANG BLAURAN SURABAYA

barang jaminan sesuai harga pasar yang berlaku.

b. Rangking resiko didasarkan pada potensi terjadinya gadai non-emas tidak tertebus dan resiko by system oleh Pegadaian Syariah sendiri.

c. Pengendalian resiko gadai non-emas tidak tertebus yang dilakukan Pegadaian Syariah Blauran yaitu:

1. Mengendalikan atau mengurangi resiko dengan cara meminta identitas resmi nasabah beserta barang jaminannya

2. Menerima atau menahan resiko dengan cara membiarkan barang yang tidak tertebus tersebut tetap berada digudang penyimpanan sampai dapat ditebus sesuai waktu yang telah disepakati atau dijual melalui lelang.

3. Menetralisasi atau mengimbangi resiko dengan cara menjual secara umum melalui lelang barang jaminan yang tidak tertebus tersebut. melalui cara ini maka Pegadaian Syariah dapat mengambil haknya yakni pokok pinjaman, biaya ijarah, dan biaya lelang. Sedangkan nasabah dapat melunasi kekurangan dari pinjaman yang dilakukan kepada Pegadaian Syariah. Jika terdapat kelebihan hasil penjualan lelang maka Pegadaian Syariah wajib mengembalikan kepada nasabah, tetapi jika tidak diambil dalam tempo satu tahun maka akan diserahkan kepada baitul maal sebagai dana kebajikan umat. Jika masih terdapat kekurangan dana dalam penjualan lelang maka nasabah wajib melunasi kekurangan tersebut.

Pemilhan Pegadaian Syariah Blauran untuk penelitian ini yaitu karena Pegadaian Syariah Blauran merupakan Pegadaian Syariah yang pertama berdiri di Surabaya. Usia Pegadaian Syariah Blauran yang sudah mencapai 12 tahun tentunya telah memberikan pengalaman yang cukup banyak dalam hal menangani risiko-risiko yang dihadapi. Selain itu data-data yang bisa dijadikan sumber informasi tentunya lebih lengkap. Hal itulah yang mendasari pemilihan Pegadaian Syariah Blauran sebagai obyek pada penelitian ini.

\section{DAFTAR PUSTAKA}

Djohanputro, Bramantyo. 2006. Manajemen Resiko Korporat Terintegrasi. Jakarta: PPM

Hasan, M. Ali. 2004. Berbagai Macam Transaksi dalam Islam. Jakarta: PT. Raja Grafindo Persada

Hendi, Suhendi. 2011. Fiqh Muamalah. Jakarta: Rajawali Pers.

Karim, A. Adhiwarman. 2001. Ekonomi Islam. Jakarta: PT. Gema Insani.

Kasmir. 2002. Bank dan Lembaga Keuangan Lainnya. Jakarta: PT. Raja Grafindo Persada.

Susilo, J dkk. 2010. Manajemen Resiko Berbasis ISO 31.000: Untuk Industri 
Cahyani, et al/Jurnal Ekonomi Syariah Teori dan Terapan Vol. 6 No. 3 Maret 2019: 446-460; PENGELOLAAN MANAJEMEN RESIKO GADAI NON-EMAS TIDAK TERTEBUS DI PEGADAIAN SYARIAH CABANG BLAURAN SURABAYA

Non-Perbankan. Jakarta: PPM

Manajemen.

Syafe'i, Rachmat. 2001. Fiqih Muamalah.

Bandung: Pustaka Setia

Tampubolon, Robert. 2006. Manajemen

Resiko: Pendekatan Kualitatif Untuk

Bank Komersial. Jakarta: PT.Elex Media Komputindo.

Yin, Robert K. 2009. Studi Kasus(Desain dan Metode). Diterjemahkan oleh Drs. M. Djauzi Mudzakir, MA. Jakarta:

PT. Raja Grafindo Persada. 